\title{
Stunting and associated factors in children of less than five years: A hospital-based study
}

\author{
Sehrish Fatima', Iram Manzoor ${ }^{2}$, \\ Aneeqa Mumtaz Joya ${ }^{3}$, Shehzeen Arif ${ }^{4}$, Sadia Qayyum ${ }^{5}$
}

\begin{abstract}
Objectives: To estimate frequency of stunting and associated factors in children aged less than five years in a tertiary care hospital of Lahore.

Methods: An Analytical cross-sectional study was conducted in Pediatrics Outpatient Department at Akhtar Saeed Trust Teaching Hospital, Lahore from December 2017 to July 2018. Two hundred children of ages under five years coming to outdoor for treatment of minor ailments were included after informed consent from their parents. Non-probability, convenient sampling technique was used to collect sample. Data collected and analyzed on SPSS version 19. To find out association of stunting with multiple qualitative variables, chi-square test was applied and $p$-value was fixed at $\leq 0.05$ to be significant.

Results: Out of 200 children screened in OPD, $42(21.0 \%)$ were found to be stunted. The total percentage of stunting in male children was $28(66.6 \%)$ and in female children were $14(33.3 \%)$. Stunting was significantly associate with male gender $(p=0.047)$, joint family system $(p=0.049)$, low literacy level in mothers $(p=0.031)$, unvaccinated status $(p=0.003)$ and history of bottle feeding $(p=0.037)$.

Conclusion: The frequency of stunting in children less than five years of age is $42(21.0 \%)$. The significant risk factors associated with stunting were found as male gender $(p=0.047)$, joint family system $(p=0.049)$, low maternal education $(p=0.031)$, unvaccinated status $(p=0.03)$.
\end{abstract}

KEYWORDS: Stunting, Vaccination status, Risk factors.

doi: https://doi.org/10.12669/pjms.36.3.1370

How to cite this:

Fatima S, Manzoor I, Joya AM, Arif S, Qayyum S. Stunting and associated factors in children of less than five years: A hospital-based study. Pak J Med Sci. 2020;36(3):581-585. doi: https://doi.org/10.12669/pjms.36.3.1370

This is an Open Access article distributed under the terms of the Creative Commons Attribution License (http://creativecommons.org/licenses/by/3.0), which permits unrestricted use, distribution, and reproduction in any medium, provided the original work is properly cited.

1. Sehrish Fatima,

2. Prof. Dr. Iram Manzoor, MBBS, FCPS, MSC, MCPS-HPE. Director Medical Education, HOD of Community Medicine,

3. Dr. Aneeqa Mumtaz Joya, MBBS, MCPS, MPH.

Assistant Professor, Department of Community Medicine,

4. Shehzeen Arif,

5. Sadia Qayyum,

$1,4,5$ : Students of $4^{\text {th }}$ Year MBBS, Community Medicine,

1-5: Akhtar Saeed Medical and Dental College,

Lahore, Pakistan.

Correspondence:

Prof. Dr. Iram Manzoor,

Director Medical Education,

HOD of Community Medicine,

Akhtar Saeed Medical and Dental College,

Lahore, Pakistan.

Email: iramdr123@yahoo.co.in

* Received for Publication:

July 18, 2019

* $1^{\text {st }}$ Revision Received:

* $\quad 2^{\text {nd }}$ Revision Received:

September 6, 2019

* Final Revision Accepted:
January 20, 2020

January 21, 2020

\section{INTRODUCTION}

Stunting is termed as reduced height for age in a sample population. ${ }^{1}$ It is a major public health issue worldwide. ${ }^{2}$ Stunted growths is one of the contributory factors of high mortality among children in low and middle income countries. ${ }^{3}$

The ideal development of children is a basic human right and an aim of health systems and social security. ${ }^{4}$ Internationally, it is estimated that $22.9 \%$ children under the age of five have growth hindrance. From 2000 to 2016, stunting gradually declined from $33.7 \%$ to $22.9 \%$ and the numbers tumbled from 198 million to 155 million. ${ }^{5}$ In 2017, a survey was conducted in thirty-six high burden countries and results showed that one out of two stunted children lived in Asia and one out of three in Africa $^{6}$ In developing countries, 200 million 
children under age five years are influenced by retarded linear growth and in those $40 \%$ fall in the category of iron deficiency anemia. ${ }^{7}$

Pakistan is one of the ten nations in the world where a greater part of less than five year old population is affected by stunting. ${ }^{8}$ As per the current situation in Pakistan, it is evaluated that almost $44 \%$ of children are stunted with predominance being marginally higher in males $(48 \%)$ than in females $(42 \%){ }^{8}$ In total, with 12 million stunted children Pakistan is positioned the third in the world. ${ }^{9}$

The major risk factor for direct cause of stunting includes poor maternal health, lack of antenatal care facilities, insufficient feeding and care, insufficient infrastructure and healthcare facilities. ${ }^{10}$ The economic wealth is a second major fundamental issue for dietary change. ${ }^{11}$ Maternal and paternal education also plays a vital role in undernutrition leading to a greater chance of stunting during primary school students. ${ }^{12}$ Relationship between younger ages of mother, birth spacing and intention of the couple for expecting a child, each has a huge association to hindered growth. ${ }^{13}$ Poor sanitation is a noteworthy general wellbeing concern connected to a few results of stunting. ${ }^{14}$ Absence of sanitation and open defecation contributes to diarrhea and spread of intestinal parasites which in return cause lack of healthy sustenance. ${ }^{15}$ Stunting in early life is associated with unfriendly consequences including poor development and instructive performance, low wages and lost productivity. ${ }^{16}$ The objective of this study was to assess the frequency and its relationship with sociodemographic profile and feeding practices which cause stunting among children.

\section{METHODS}

A cross sectional survey was conducted at an outpatient department of pediatrics of Akhtar Saeed Trust Hospital during December 2017 to July 2018. This study was conducted on a sample of 200 children, less than five years coming to outdoor for treatment of minor ailments. Data was collected after taking consent from the parents. Children with congenital and severe illness were excluded. Before data collection of this study, IRB approval (No. M-18/21/-CM) was taken in February 6, 2018. Non probability convenient sampling technique was used to recruit sample of 200 children. A structured questionnaire was used to collect data regarding sociodemographic profile, height and feeding practices of these children. Data was entered and analyzed in SPSS version 19 and was presented in the form of frequency tables and graphs. Chi square test of significance was applied to find out association between sociodemographic factors and stunting pattern and $p$ value was fixed at $\leq 0.05$ to declare results as significant.

\section{RESULTS}

The mean age of the sample was $24.33 \pm 16.256$ months (Fig.1).

There were 200 participants in total, out of which $110(55 \%)$ males and $90(45 \%)$ females respectively. One hundred and sixteen (58\%) participants belonged to urban areas. Out of 200, 105 (52.5\%) belonged to joint family system. Educational status for fathers showed only $32(16 \%)$ had done graduation and post-graduation. Same results were obtained with maternal education status and higher education was observed only in $27(13.5 \%)$. Drinking water supply available in households was through government source in only $106(53 \%)$. The mean income was estimated to be Rs. 20,300. 123 $\pm 13,759.96$ (Table-I).

One hundred sixteen (58\%) children had complete vaccination status, $79(39.5 \%)$ for incomplete and $5(2.5 \%)$ never received even a single dose of vaccination.

History of breastfeeding was found in 166(83\%) of the children but it was also accompanied with bottle feeding in $161(80.5 \%)$. Only $19.5 \%$ of the

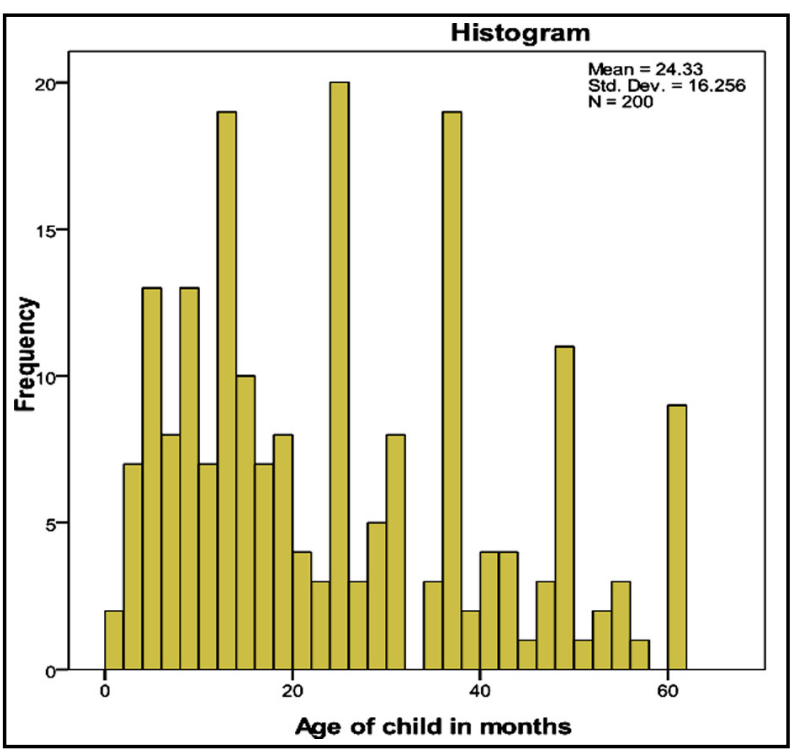

Fig.1: Graphical distribution of age in children (in months). 
Table-I: Sociodemographic profile of children less than five years of age.

\begin{tabular}{|c|c|c|}
\hline & $\begin{array}{l}\text { Frequency } \\
\text { (n) }\end{array}$ & $\begin{array}{c}\text { Percentage } \\
(\%)\end{array}$ \\
\hline \multicolumn{3}{|l|}{ Gender distribution } \\
\hline Male & 110 & 55 \\
\hline Female & 90 & 45 \\
\hline \multicolumn{3}{|l|}{ Area of distribution } \\
\hline Rural & 84 & 42 \\
\hline Urban & 116 & 58 \\
\hline \multicolumn{3}{|l|}{ Family type } \\
\hline Nuclear & 95 & 47.5 \\
\hline Joint & 105 & 52.5 \\
\hline \multicolumn{3}{|c|}{ Educational status of mothers } \\
\hline Uneducated & 69 & 34.5 \\
\hline Primary & 79 & 39.5 \\
\hline Secondary & 25 & 12.5 \\
\hline Graduate & 20 & 10.0 \\
\hline Postgraduate & 7 & 3.5 \\
\hline \multicolumn{3}{|c|}{ Educational status of fathers } \\
\hline Uneducated & 64 & 32.0 \\
\hline Primary & 67 & 33.5 \\
\hline Secondary & 37 & 18.5 \\
\hline Graduate & 18 & 9.0 \\
\hline Postgraduate & 14 & 7.0 \\
\hline \multicolumn{3}{|l|}{ Monthly income } \\
\hline Below Rs 20,000 & 123 & 61.5 \\
\hline Above Rs 20,000 & 77 & 38.5 \\
\hline
\end{tabular}

participants were exclusively breastfed by their mothers. About $22.5 \%$ of the mothers believed that their feeding practices are inadequate for

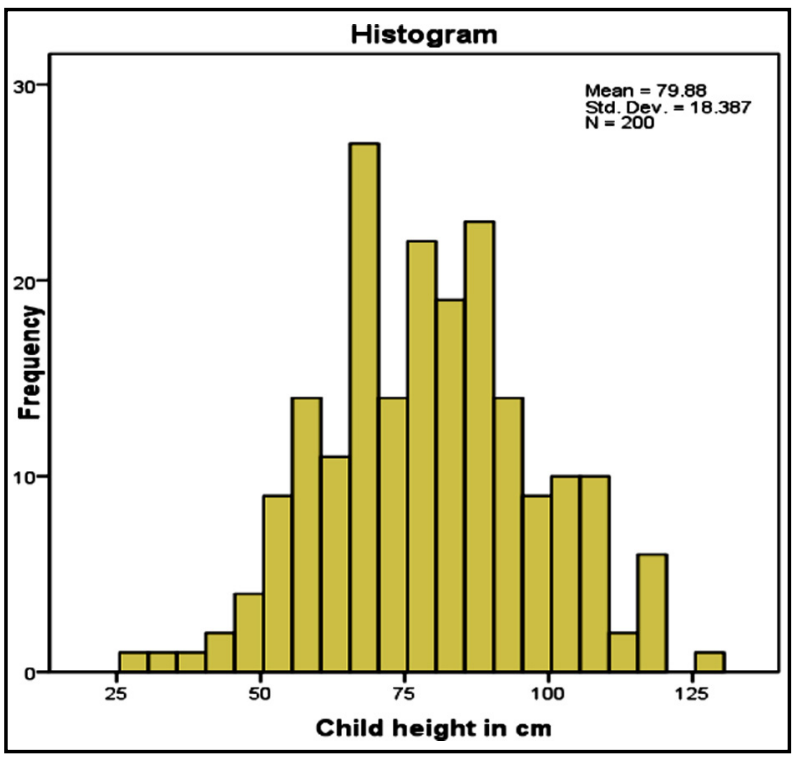

Fig.2: Mean distribution according to height of participants.
Table-II: Feeding pattern of children.

\begin{tabular}{lcc}
\hline & $\begin{array}{c}\text { Frequency } \\
(n)\end{array}$ & $\begin{array}{c}\text { Percentage } \\
(\%)\end{array}$ \\
\hline $\begin{array}{l}\text { Feeding practices } \\
\text { 4 or more small meals } \\
\text { (Adequate feeding) }\end{array}$ & 155 & 77.5 \\
$\begin{array}{l}\text { Less than 4 small meals } \\
\text { (Inadequate feeding) }\end{array}$ & 45 & 22.5 \\
$\begin{array}{l}\text { Breast feeding } \\
\text { Yes }\end{array}$ & & \\
No & 166 & 83 \\
Bottle feeding & 34 & 17 \\
Yes & & \\
No & 161 & 80.5 \\
\hline
\end{tabular}

their kids (Table-II) Majority of the participants relied on three meals per day. Mean meals $2.99 \pm 1.109$ were taken.

The mean height was $78.88 \pm 19.258 \mathrm{~cm}$ (Fig.2). The researchers have used reference curves developed by WHO to assess the status of stunting. After application of test of significance, results showed that stunting was strongly associated with male gender $(p=0.047)$, joint family system $(p=0.049)$, maternal education $(0.031)$, incomplete vaccination status $(0.003)$ and history of bottle feeding (0.037).

\section{DISCUSSION}

The study findings showed significant association with male gender of the child which is considered as being a solid determinant of stunting in children under five years of age. Some past studies from Sub Saharan Africa have shown that males are increasingly affected when contrasted with females. ${ }^{17}$ There is a common conviction that in Pakistan parents are strict with their daughters than their sons and often give unique consideration to the male child is not supported by this survey.

Consistent with findings of other similar studies there was no significant urban-rural disparity with stunted growth in this study. Patients who reported to the hospital resided in nearby vicinity and had availability to better healthcare facilities, water supply and improved sanitation. A study done in Bangladesh suggests that more than fifty percent living in urban slums had a higher prevalence of stunting. ${ }^{18}$ Contrary to this, another study conducted in Gaza in 2010 suggests predominance of stunting in the urban territory was higher than the rural areas. ${ }^{19}$ This outcome could be due to poor economic conditions. 
The results of this study showed significant association between stunted growth and joint family system. A study conducted in a village of Nepal suggested that children living in joint families were found to be less inclined to being underweight and stunted. This was due to the fact that mothers are field workers and they might be physically unfit to nurture their newborn consistently. In such circumstances, in joint families, there are dependable people like grandparents. ${ }^{20}$ But these findings don't match with results of this study due to high dependency ratio in joint family systems of Pakistan.

Maternal education has been demonstrated to be significant for a child's wellbeing and survival. Similar findings were observed in this study showing, significant link between stunted growth and lower maternal education status. According to a study carried out in Bolivia there was significant association between them. ${ }^{21}$ There is proof from Indonesia and Bangladesh that maternal education has a protective impact on stunting. ${ }^{22}$ Contrary to these findings there was no significant association found between educational status of fathers and stunting.

The first thousand days of life are a critical period to prevent risk factors of stunting. ${ }^{16}$ Therefore; more consideration ought to be given to the wellbeing and living conditions occurring at that developmental stage. Analysis of this study showed significant association between bottle feeding practices and stunted growth of children. Some findings have been supported by other developing countries, as a study on Malawian infants suggested that administration of any other fluid other than breast milk particularly before the age of four months, is related with gastrointestinal issues. This may result in stunting, micronutrient insufficiencies and vulnerability towards different illness within the first few years of life..$^{23}$ In our study, food insecurity was excluded as a related factor of stunting, but various studies have reported that it influences the wellbeing and has been linked to child's intake and weight. ${ }^{24,25}$ Food insecurity might be identified with protein energy malnutrition, which was obvious in cases of stunting. ${ }^{26,27}$

The significant result in our survey was that the incomplete/no vaccination status were strongly associated with stunting. A study carried out in Nairobi had similar findings. ${ }^{28}$ In Tanzania, Zambia, Madagascar and Zimbabwe immunization were given altogether and as a result dietary status was improved and health gains were achieved..$^{29}$ Immunization in children is a protective measure in order to avoid various childhood diseases and stunting. ${ }^{30}$ To reduce the burden of stunting in developing countries, major emphasis should be laid on improving the sociodemographic profile, promotion of breast feeding and vaccination practices.

Limitations of the study: Data based on a hospitalbased sample. Such studies should be conducted in communities to have comparable results.

\section{CONCLUSION}

Male gender, children residing in joint family system, children with uneducated mothers, children with incomplete/no vaccination history and fed on bottle feeding are at high risk of developing stunting.

Recommendations: Promotion of exclusive breast feeding and vaccination practices among parents can reduce burden of stunting in Pakistani children.

Grant Support E Financial Disclosures: None.

\section{REFERENCES}

1. World Health Organization. Guideline: assessing and managing children at primary health-care facilities to prevent overweight and obesity in the context of the double burden of malnutrition. World Health Organization; 2017.

2. De Onis M, Branca F. Childhood stunting: A global perspective. Matern Child Nutr. 2016;12(1):12-26. doi: 10.1111/mon.12231

3. Black RE, Victora CG, Walker SP, Bhutta ZA, Christian P, De Onis $M$, et al. Maternal and child undernutrition and overweight in low-income and middle-income countries. Lancet. 2013;382(9890):427-451. doi: 10.1016/S01406736(13)60937-X

4. Onis MD, FrongilloEA, Blossner M. Is malnutrition declining? An analysis of changes in levels of child malnutrition since 1980. Bull World Health Organ. 2000;78(10):1222-1233. doi: 10.1590/S0042-96862000001000008

5. De Onis M. Child growth and development. In Nutrition and Health in a Developing World 2017(pp.119-141). https:// www.researchgate.net/publication/313732276_ Child_Growth_and_Development

6. De Onis M, Blössner M, Borghi E. Prevalence and trends of stunting among pre-school children, 1990-2020. Public Health Nutr. 2012;15(1):142-148. doi: 10.1017/ S1368980011001315

7. World Health Organization. Indicators for assessing infant and young child feeding practices. Part 1. definitions: conclusions of a consensus meeting held 6-8 November 2007 in Washington, DC, USA.

8. World Health Organization. The work of WHO in the Eastern Mediterranean Region: Annual report of the Regional Director 2014. World Health Organization. Regional Office for the Eastern Mediterranean; 2015. 
9. Shah SM, Selwyn BJ, Luby S, Merchant A, Bano R. Prevalence and correlates of stunting among children in rural Pakistan. Pediatr Int. 2003;45(1):49-53. doi: 10.1046/j.1442200x.2003.01652.x

10. World Health Organization, The Healthy Growth Project, Conceptual Framework 'Stunted Growth and Development -Context, Causes and Consequences', retrieved February 2017

11. Headey D, Hoddinott J, Ali D, Tesfaye R, Dereje M. The other Asian enigma: Explaining the rapid reduction of undernutrition in Bangladesh. World Dev. 2015;66:749-761. doi: 10.1016/j.worlddev.2014.09.022

12. Mushtaq MU, Gull S, Khurshid U, Shahid U, Shad MA Siddiqui AM. Prevalence and socio-demographic correlates of stunting and thinness among Pakistani primary school children. BMC Public Health. 2011;11(1):790. doi: 10.1186/1471-2458-11-790

13. Rahman MM. Is Unwanted birth associated with child malnutrition in Bangladesh? Int Perspect Sex Reprod Health. 2015;41(2):80-88. doi: 10.1363/4108015

14. Spears D, Ghosh A, Cumming O. Open defecation and childhood stunting in India: An ecological analysis of new data from 112 districts. PloS One. 2013;8(9):e73784. doi: 10.1371 /journal.pone.0073784

15. World Health Organization, UNICEF. Improving nutrition outcomes with better water, sanitation and hygiene: practical solutions for policies and programmes. 2015 available at: https://www.who.int/water_sanitation health/publications/washandnutrition/en/ Accessed on July 15, 2019

16. Victora CG, Adair L, Fall C, Hallal PC, Martorell R, Richter L, et al. Maternal and child undernutrition: Consequences for adult health and human capital. Lancet. 2008;371(9609):340357. doi: 10.1016/S0140-6736(07)61692-4

17. Ndiku M, Jaceldo-Siegl K, Singh P, Sabate J. Gender inequality in food intake and nutritional status of children under 5 years old in rural Eastern Kenya. Eur J Clin Nutr. 2011;65(1):26-31. doi: 10.1038/ ejcn.2010.197

18. Ahsan KZ, El Arifeen S, Al-Mamun MA, Khan SH, Chakraborty N. Effects of individual, household and community characteristics on child nutritional status in the slums of urban Bangladesh. Arch Public Health. 2017;75(1):9. doi: 10.1186/s12992-018-0372-7

19. World Health Organization. Health conditions in the occupied Palestinian territory, including east Jerusalem, and in the occupied Syrian Golan. Geneva: World Health Organization; 2009.

20. Pramod Singh GC, Nair M, Grubesic RB, Connell FA. Factors associated with underweight and stunting among children in rural Terai of eastern Nepal. Asia-Pac J Public Health. 2009;21(2):144-152. doi: 10.3389/fpubh.2017.00350

21. Bhutta ZA, Ahmed T, Black RE, Cousens S, Dewey K, Giugliani E, et al. What works? Interventions for maternal and child undernutrition and survival. Lancet. 2008;371(9610):417-440. doi: 10.1016/S01406736(07)61693-6
22. Semba RD, de Pee S, Sun K, Sari M, Akhter N, Bloem MW. Effect of parental formal education on risk of child stunting in Indonesia and Bangladesh: A cross-sectional study. Lancet. 2008;371(9609):322-328. doi: 10.1016/ S0140-6736(08)60169-5

23. Oh S, Hong M. Food insecurity is associated with dietary intake and body size of Korean children from low-income families in urban areas. Eur J Clin Nutr. 2003;57(12):15981604. doi: 10.1038/sj.ejcn.1601877

24. Cook JT, Frank DA. Food insecurity, poverty, and human development in the United States. Ann N Y Acad Sci. 2008;1136(1):193-209. doi: 10.1196/annals.1425.001

25. Baig Ansari N, Rahbar MH, Bhutta ZA, Badruddin SH. Child's gender and household food insecurity are associated with stunting among young Pakistani children residing in urban squatter settlements. Food Nutr Bull. 2006;27(2):114-127. doi: 10.1177/156482650602700203

26. Phengxay M, Ali M, Yagyu F, Soulivanh P, Kuroiwa C, Ushijima $\mathrm{H}$. Risk factors for protein-energy malnutrition in children under 5 years: Study from Luangprabang province. Laos Pediatr Int. 2007;49(2):260-265. doi: 10.1111/j.1442200X.2007.02354.x

27. Kramer MS, Guo T, Platt RW, Sevkovskaya Z, Dzikovich I, Collet JP, et al. Infant growth and health outcomes associated with 3 compared with 6 mo of exclusive breastfeeding. Am J Clin Nutr. 2003;78(2):291-295.

28. Faye CM, Fonn S, Levin J. Factors associated with recovery from stunting among under-five children in two Nairobi informal settlements. PloS One. 2019;14(4):e0215488. doi: 10.1371/journal.pone.0215488

29. Doherty T, Chopra M, Tomlinson M, Oliphant N, Nsibande D, Mason J. Moving from vertical to integrated child health programmes: Experiences from a multicountry assessment of the Child Health Days approach in Africa. Trop Med Int Health. 2010;15(3):296-305. doi: 10.1111/j.1365-3156.2009.02454.x

30. Shah SM, Selwyn BJ, Luby S, Merchant A, Bano R. Prevalence and correlates of stunting among children in rural Pakistan. Pediatr Int. 2003;45(1):49-53. doi: 10.1046/j.1442200x.2003.01652.x

\section{Authors' Contribution:}

SF: Conceptualization, discussion write up.

IM: Analysis and results write up. Accountable for accuracy and integrity.

AMJ: Introduction write up.

SA: Questionnaire development, data collection.

SQ: Methodology write up and data collection. 